\title{
Color of Corn Grains and Carotenoid Profile of Importance for Human Health
}

\author{
Sara de Almeida Rios ${ }^{1}$, Maria Cristina Dias Paes², Wilton Soares Cardoso³, \\ Aluízio Borém ${ }^{4}$, Flávia França Teixeira ${ }^{2}$ \\ ${ }^{1}$ Embrapa Western Amazon, Manaus, Brazil \\ ${ }^{2}$ Embrapa Maize and Sorghum, Sete Lagoas, Brazil \\ ${ }^{3}$ Federal Institute of Education, Science and Technology of the Espírito Santo, IFES, Venda Nova do Imigrante, \\ Brazil \\ ${ }^{4}$ Federal University of Viçosa, Viçosa, Brazil \\ Email: sara.rios@embrapa.br
}

Received 8 January 2014; revised 21 February 2014; accepted 11 March 2014

Copyright (C) 2014 by authors and Scientific Research Publishing Inc.

This work is licensed under the Creative Commons Attribution International License (CC BY). http://creativecommons.org/licenses/by/4.0/

(c) (i) Open Access

\begin{abstract}
The increasing on the levels of carotenoids in staple foods of broad human consumption is one of the strategies of food biofortification programs, mainly due to the importance of these compounds to human health on the prevention of vitamin A deficiency. Maize is a major staple food due to its high consumption in regions where problems of Vitamin A deficiency are of great relevance. Maize biofortification programs have made progress in determining the amounts of carotenoids in grain of thousands of accesses. This work aimed at studying the influence of the color of the grains in the profile of carotenoids in four different Brazilian genotypes. The selection of ears within the same genotype was based on a color scale, considering the lighter (lightest yellow) in one group and the most colorful (darkest orange) in another group. Significant interactions $(p<0.05)$ between the color of the grains and the genotypes for all the variables were detected in addition to genetic variability for both groups (lightest yellow and darkest orange). The colored ears of corn showed a high level of total carotenoids (TC) and fractions in RS 535 and RS 445, and the colorful ears of genotype RS 535 showed $300 \%$ more $\alpha+\beta$ carotenes $\left(\mu \mathrm{g} \cdot \mathrm{g}^{-1}\right)$ in relation to lighter of this same material. The results of this study showed the influence of genotype on the grain color and content of carotenoids, indicating that breeders have the flexibility to make selection of some genotypes based on grain color, reducing cost and time compared to laboratory methods used for the screening of genetic materials.
\end{abstract}

\section{Keywords}

Carotenes; Zea mays; Vitamin A; Genetic Variability; Biofortification

\footnotetext{
"Corresponding author.
}

How to cite this paper: de Almeida Rios, S., Paes, M.C.D., Cardoso, W.S., Borém, A. and Teixeira, F.F. (2014) Color of Corn Grains and Carotenoid Profile of Importance for Human Health. American Journal of Plant Sciences, 5, 857-862. 


\section{Introduction}

Carotenoids are a family of more than 600 liposoluble compounds found in plants, microorganisms, animals and some invertebrates [1]. About 50 carotenoids have pro-vitamin A activity, and the $\beta$-carotene has the highest activity [2] and for this reason, has been considered as a compound of interest in breeding programs for generation of biofortified crops, especially in edible portions of these plants. These compounds have great importance for human health, acting in mechanisms related to cancer, cardiovascular disease and macular degeneration prevention in humans as well as vitamin A deficiency [3]-[6].

Maize is a carotenogenic plant [7] and a staple food for more than 1 billion and 200 million consumers in Africa and Latin America regions where more than 50 millions people present vitamin A deficiency [8]. The carotenoids present in corn grain are classified into carotenes ( $\beta$-caroteno e $\alpha$-caroteno) and xanthophylls (lutein, zeaxanthin and $\beta$-criptoxanthin), with higher concentrations of lutein and zeaxanthin compared to other carotenoids [9].

Changes in carotenoid profile in the corn kernel have been reported with direct influence of genotype $\mathrm{x}$ environment interaction [9]-[12], existing relationship between the yellow or orange color of the endosperm and the presence of carotenoids [13] [14]. However, little information is available in the literature that allows relating the intensity of the grain color and the profile of carotenoids and other fractions of biological relevance to human health. The phenotypic selection based on ear color could provide greater speed and economy in breeding programs aiming at the increase of carotenoids in corn, since the chemical analyses for the quantitation of these compounds are costly and time consuming. This study was conducted to evaluate the association between color kernel intensity and the profile of carotenoids of importance for human nutrition.

\section{Materials and Methods}

In this work four genotypes (BA 178, RS 445, RS 535 and SP 586) of the Embrapa Active Maize Germplasm Bank were analyzed for carotenoid profile. Maize types, locations and geographical positions were given in the Table 1. The accessions were multiplied in the experimental field of Embrapa, located in Nova Porteirinha, latitude $15^{\circ} 48^{\prime} 9^{\prime \prime} \mathrm{S}$, longitude $43^{\circ} 18^{\prime} 2^{\prime \prime} \mathrm{W}$ and altitude of $533 \mathrm{~m}$. The fertilizing was done using the 8-28-16 + Zn at $400 \mathrm{~kg} \cdot \mathrm{ha}^{-1}$, and $90 \mathrm{~kg} \cdot \mathrm{ha}^{-1}$ of $\mathrm{N}$ topdressing at 40 days after planting. Plots consisted of two rows of four meters long, with spacing of $0.90 \mathrm{~m}$ between rows and a final stand of approximately 55,000 plants per hectare.

The ears were harvested at the reproductive stage R3 [15] from the central area of each plot. The selection of ears within the same genotype was based on a visual color scale (Figure 1), considering the lighter (lightest yellow) in one group and the most colorful (darkest orange) in another group. The ears of these two groups were threshed separately in mechanical threshers. The grains were piled evenly on a clean surface, flattened and spread into a circle. It was made a cross, dividing the circle into four roughly equal parts (Figure 2).

It were discarded two diametrically opposite quarters and remixed the remaining two quarters. This procedure of quartering [2] was repeated until the amount was reduced to approximately $250 \mathrm{~g}$. The dried seeds (moisture $12 \%$ ) were ground to a fine consistency in a cyclone mill model MA 020 MARCONI, coupled with $0.5 \mathrm{~mm}$ sieve (Piracicaba-SP). The samples were packed in glass vials sealed with a lid, wrapped in aluminum foil until subsequent chemical analyzes.

Grains were rehydrated with cold acetone to allow efficient absorption. It was used $3 \mathrm{~g}$ of ground corn, added of sufficient water to cover it (about $10 \mathrm{~mL}$ ), allowed to stand for 30 minutes. After it, was added about $20 \mathrm{~mL}$ of cold acetone for 15 minutes until initiate the filtration and suction through a sintered glass funnel. The

Table 1. Data for maize accessions (Zea mays L.) from the Active Maize Germplasm Bank of Embrapa Maize and Sorghum.

\begin{tabular}{cccc}
\hline Acession & Origin ${ }^{*}$ & Latitude & Longitude \\
BA 178 & Bahia & $13^{\circ} 26^{\prime} \mathrm{S}$ & $44^{\circ} 9^{\prime} \mathrm{W}$ \\
RS 445 & Rio Grande do Sul & $27^{\circ} 37^{\prime} \mathrm{S}$ & $54^{\circ} 18^{\prime} \mathrm{W}$ \\
SP 586 & São Paulo & $23^{\circ} 5^{\prime} \mathrm{S}$ & $45^{\circ} 38^{\prime} \mathrm{W}$ \\
RS 535 & Rio Grande do Sul & $29^{\circ} 20^{\prime} \mathrm{S}$ & 457 \\
\hline
\end{tabular}

\footnotetext{
*Bazilian States.
} 


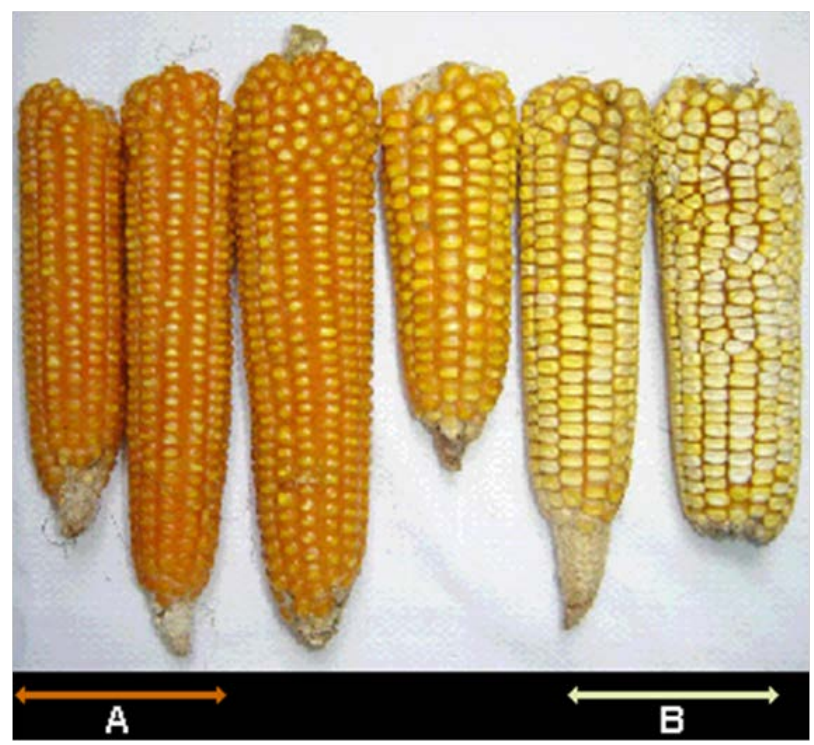

Figure 1. Color Scale utilized to separate the ears within the same genotype from the Active Maize Germplasm Bank of Embrapa Maize and Sorghum, according to two levels of intensity of color: A (darkest orange) and B (lightest yellow).

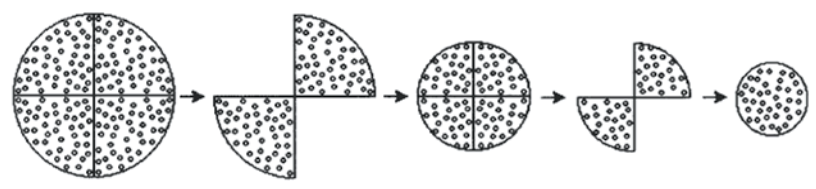

Figure 2. Illustration of quartering of grains and flours. Source: Rodriguez-Amaya \& Kimura (2004).

solid was placed in a mortar, ground well with the pestle, added about $50 \mathrm{~mL}$ of cold acetone (acetone refrigerated for about 2 hours), and ground again with the pestle to extract the carotenoids. It was filtered through the same funnel, collecting the acetone extract in the same suction flask. After, the mortar, pestle, funnel, and residue were washed with small amounts of acetone, receiving the washings in the suction flask with the extract. The residue was returned to the mortar, added $50 \mathrm{~mL}$ of fresh cold acetone, macerated and filtered as before. The extraction was repeated until the residue stand colorless. The partition was made with $20 \mathrm{~mL}$ of petroleum ether (PE) in a separatory funnel adding one-third of the extract each time. After each addition, it was slowly added distilled water $(\sim 300 \mathrm{~mL})$, letting it flow along the wall of the funnel to avoid formation of an emulsion. After separation of the two phases, it was discarded the aqueous acetone phase. The operation was repeated for the second and third portion. After, the third portion has been transferred to PE, washing 3 times with water to remove residual acetone. In the last washing, it was discarded the lower phase as completely as possible, without discarding any of the upper phase that was collected in a $25 \mathrm{~mL}$ volumetric flask, passing it through a funnel with anhydrous sodium sulfate to remove residual water. An aliquot of $20 \mathrm{~mL}$ was used to the separation of the fractions and the remaining extract was used to measure the absorbance at $450 \mathrm{~nm}$ (A total).

The levels of total carotenoids was quantified by spectrophotometric readings performed in a spectrophotometer Cary 50 Conc UV-Visible (Varian, Australia) and the separation of carotenes ( $\alpha+\beta$-carotene), xanthophylls (lutein and zeaxanthin) and $\beta$-cryptoxanthin was made in a minicolumn according to the screening method for dry grains, described by Rodriguez-Amaya \& Kimura [2]. Samples were analyzed for moisture according to AACC [16], and concentrations of carotenoids were expressed on a dry basis.

The experimental design was a completely randomized in a factorial scheme $4 \times 2$ with four genotypes (BA 178, RS 445, RS 535 and SP 586) and two intensities of the colors ears (lighter and colorful), with 2 repetitions and two replicates of laboratory. Data were subjected to analysis of variance and means compared by Tukey test at $5 \%$ of probability using the Genes software [17]. 


\section{Results and Discussion}

Significant interactions ( $\mathrm{p}<0.05$ ) between the color of the grains and genotypes were detected for all variables. The averages for the levels of total carotenoids (TC) and carotenes are presented in Table 2.

Phenotypic variability was observed among genotypes for the levels of TC and some fractions for both lightest yellow and darkest orange ears. Compared to other cereals, maize has the highest phenotypic variability for $\beta$-carotene, $\beta$-cryptoxanthin and $\alpha$-carotene, which are the three fractions of carotenoids showing pro-vitamin A activity [18].

Within genotypes BA 178 and SP 586 there was no significant difference between lighter and colorful ears, to the contents of TC, carotenes, xanthophylls and $\beta$-cryptoxanthin. The RS 445 and RS 535 genotypes presented averages for the contents of TC, $\alpha+\beta$ carotene, $\beta$-cryptoxanthin and lutein + zeaxanthin in colorful ears statistically higher compared to the levels observed in the lighter, indicating the possible existence of a positive linear relationship between selection of the colorfull (darkest orange) ears and specific profiles of carotenoids, for these materials.

Grains of all genotypes showed averages of $\alpha+\beta$ carotenes statistically equal, considering the lighter color of the ears. However, colorful ears, the RS 535 genotype had the highest average compared to those observed in BA 178 and SP 586 (Table 2). The colorful ears of genotype RS 535 showed 300\% more $\alpha+\beta$ carotenes $\left(\mu \mathrm{g} \cdot \mathrm{g}^{-1}\right)$ in relation to lighter of this same material (Table 2$)$.

The mean values found for $\alpha+\beta$ carotenes in lighter ears $\left(3.35 \mu \mathrm{g} \cdot \mathrm{g}^{-1}\right)$ and in colorful ones $\left(6.58 \mu \mathrm{g} \cdot \mathrm{g}^{-1}\right)$ were much higher than the data presented by the USDA [19], which lists average of $1.6 \mu \mathrm{g} \cdot \mathrm{g}^{-1}$ of $\alpha+\beta$ carotene. This superiority was also observed for lutein + zeaxanthin, in the evaluated genotypes (Table 2), which was $20.35 \mu \mathrm{g} \cdot \mathrm{g}^{-1}$ compared to $13.55 \mu \mathrm{g} \cdot \mathrm{g}^{-1}$ reported by USDA [19]. The variation in levels of TC was $15.30 \mu \mathrm{g} \cdot \mathrm{g}^{-1}$ to $44.45 \mu \mathrm{g} \cdot \mathrm{g}^{-1}$ (Table 2), demonstrating the genetic potential of these genotypes for biofortification programs, especially considering the variation of $10.83 \mu \mathrm{g} \cdot \mathrm{g}^{-1}$ to $42.84 \mu \mathrm{g} \cdot \mathrm{g}^{-1}$ for total carotenoids in maize lines of the Brazilian Maize biofortification program [20]. It is possible that even the lighter ears of genotypes have potential to be used in populations of eastern and southern Africa. Despite the preference of these populations for the white corn [14] [21] recent studies have shown that orange maize has well been accepted after the disclosure of their nutritional importance and, some populations prefer their flavor compared to the aroma of local white varieties [22] [23].

Regarding the phenotype color, there was significant difference $(\mathrm{p}<0.05)$ with colorful ears presenting higher levels of TC and fractions, especially for the provitamin A carotenoids, considering the content of RS 535 and RS 445 (Tables 2 and 3). This result contradicts Harjes et al. [24] that relate the orange color of endosperm to a positive correlation with total carotenoids, but with a weak positive linear relationship with carotenoids provitamin A. Other authors also relate the largest yellow color to carotenoids non provitamin A [25] [26].

Our results demonstrated the influence of the genotype effect on these relations, once the other genotypes (BA 178 and SP 586), there was no statistical difference between the color of ear and the content of TC and fractions (Tables 2 and 3). Harjes et al. [24] reported the importance of continued selection for orange ears, which should result in high levels of TC, adding however, that this must be accompanied by marker-assisted selection to specifically increase the proportion of provitamin A carotenoids. According to Kandianis et al. [18] the marker-assisted selection has been shown to increase levels of provitamin A by the concentration of the favorable al-

Table 2. Total carotenoids and carotenes in genotypes from the Active Maize Germplasm Bank of Embrapa Maize and Sorghum, Sete Lagoas/MG, according to the color of the ear ${ }^{1}$.

\begin{tabular}{|c|c|c|c|c|c|c|c|c|}
\hline \multirow{3}{*}{$\begin{array}{l}\text { Accession } \\
\text { BA } 178\end{array}$} & \multicolumn{4}{|c|}{ Total Carotenoids $\left(\mu \mathrm{g} \cdot \mathrm{g}^{-1}\right)$} & \multicolumn{4}{|c|}{$\alpha+\beta$ carotenes $\left(\mu \mathrm{g} \cdot \mathrm{g}^{-1}\right)$} \\
\hline & \multicolumn{2}{|c|}{ Lighter } & \multicolumn{2}{|c|}{ Colorful } & \multicolumn{2}{|c|}{ Lighter } & \multicolumn{2}{|c|}{ Colorful } \\
\hline & 23.81 & Аа & 30.05 & $\mathrm{Ab}$ & 3.24 & Аа & 4.62 & Abc \\
\hline RS 445 & 25.79 & $\mathrm{Ba}$ & 44.45 & Aa & 2.88 & $\mathrm{Ba}$ & 7.43 & Aab \\
\hline RS 535 & 15.30 & $\mathrm{Bb}$ & 42.44 & Aa & 2.79 & $\mathrm{Ba}$ & 8.63 & Аа \\
\hline SP 586 & 31.66 & Аа & 37.67 & Aab & 4.50 & Аа & 5.63 & $\mathrm{Ab}$ \\
\hline
\end{tabular}

Means followed by the same uppercase letter (line) and the lowercase letter (column) do not differ by Tukey test at $5 \%$ probability. ${ }^{1}$ Means were expressed on a dry weight basis. 
Table 3. Carotenoids $\beta$-criptoxanthin and lutein + zeaxanthin in genotypes from the Active Maize Germplasm Bank of Embrapa Maize and Sorghum, Sete Lagoas/MG, acording to the color of the ear ${ }^{1}$.

\begin{tabular}{|c|c|c|c|c|c|c|c|c|}
\hline \multirow{3}{*}{$\begin{array}{c}\text { Accession } \\
\text { BA } 178\end{array}$} & \multicolumn{4}{|c|}{$\beta$-criptoxanthin $\left(\mu \mathrm{g} \cdot \mathrm{g}^{-1}\right)$} & \multicolumn{4}{|c|}{ Lutein + zeaxanthin $\left(\mu \mathrm{g} \cdot \mathrm{g}^{-1}\right)$} \\
\hline & \multicolumn{2}{|c|}{ Lighter } & \multicolumn{2}{|c|}{ Colorful } & \multicolumn{2}{|c|}{ Lighter } & \multicolumn{2}{|c|}{ Colorful } \\
\hline & 3.96 & $\mathrm{Ab}$ & 4.86 & $\mathrm{Ab}$ & 16.62 & $\mathrm{Aa}$ & 20.57 & $\mathrm{Aa}$ \\
\hline RS 445 & 5.19 & $\mathrm{Ba}$ & 9.80 & Aa & 16.2 & $\mathrm{Bab}$ & 27.95 & Aa \\
\hline RS 535 & 3.45 & $\mathrm{Bb}$ & 8.48 & Aa & 9.07 & $\mathrm{Bb}$ & 25.34 & Aa \\
\hline SP 586 & 6.10 & $\mathrm{Aa}$ & 6.06 & $\mathrm{Ab}$ & 21.07 & $\mathrm{Aa}$ & 25.98 & $\mathrm{Aa}$ \\
\hline
\end{tabular}

Means followed by the same uppercase letter (line) and the lowercase letter (column) do not differ by Tukey test at $5 \%$ probability. ${ }^{1}$ Means were expressed on a dry weight basis.

leles of the carotenoid biosynthetic genes lcyE (lycopene epsilon cyclase) [24] and crtRB1 (b-carotene hydroxylase 1) [27].

\section{Conclusion}

The color of the corn grain influences the concentration of carotenoids in the kernels and this response is dependent of the genoype, indicating that breeders have flexibility to make selection of some genotypes based on grain color for concentration of carotenoids, reducing cost and time compared to laboratory methods used for the screening of genetic materials, but this does not dispense the necessity of chemical analyses considering the profile of carotenoids.

\section{Acknowledgements}

The authors thank the Harvest Plus and Embrapa (Brazilian Agricultural Research Corporation), for funding these research activities.

\section{References}

[1] Britton, G. (2005) Structure and Properties of Carotenoids in Relation to Function. FASEB Journal, 9, 1551-1558.

[2] Rodriguez-Amaya, D.B. and Kimura, M. (2004) Harvest Plus Handbook for Carotenoid Analysis. Washington, DC and Cali: IFPRI and CIAT, 58. (Harvest Plus Technical Monograph, 2).

[3] Rios, S.A., Paes, M.C.D., Abreu, S.C. and Cardoso, W.S. (2011) Deficiências Nutricionais e a Biofortificação de Alimentos. In: Borém, A. and Rios, S.A., Eds., Milho Biofortificado, Suprema, Visconde do Rio Branco, 9-21.

[4] Pelissari, F.M., Rona, M.S.S. and Matioli, G. (2008) O Licopeno e suas Contribuições na Prevenção de Doenças. Arquivos do Mudi, 12, 5-11.

[5] FAO. Chapter 7 (2002) Vitamin A. World Health Organization for Food and Agriculture Organization of the United Nations Rome. http://www.fao.org/docrep/004/y2809e/y2809e0d.htm

[6] Vallabhaneni, R. and Wurtzel, E.T. (2009) Timing and Biosynthetic Potential for Carotenoid Accumulation in Genetically Diverse Germplasm of Maize. Plant Physiology, 150, 562-572. http://dx.doi.org/10.1104/pp.109.137042

[7] Rodriguez-Amaya, D.B. (2001) A Guide to Carotenoid Analysis in Foods. ILSI Human Nutrition Institute. One Thomas Circle, NW, Washington DC, 20005-5802, 64.

[8] CIMMYT (2013) Milho Biofortificado. http://r4d.dfid.gov.uk/PDF/Outputs/Misc Crop/harvestplus-maizepo.pdf

[9] Kurilich, A.C. and Juvik J.A. (1999) Quantification of Carotenoid and Tocopherol Antioxidants in Zea mays. Journal of Agricultural and Food Chemistry, 47, 1948. http://dx.doi.org/10.1021/jf981029d

[10] Egesel, C.O., Wong, J.C., Lambert, R.J. and Rocheford, T.R. (2003) Combining Ability of Maize Inbreds for Carotenoids and Tocopherols. Crop Science, 43, 818-823. http://dx.doi.org/10.2135/cropsci2003.8180

[11] Egesel, C.O., Wong, J.C., Lambert, R.J. and Rocheford, T.R. (2004) Gene Dosage Effects on Carotenoid Concentration in Maize Grain. Maydica, 48, 183-190.

[12] Rios, S.A. (2008) Interação Genótipos x Ambientes para Carotenóides em Cultivares de Milho. 65 f. Ph.D. dissertation, Universidade Federal de Viçosa, Viçosa.

[13] Palaisa, K.A., Morgante, M., Williams, M. and Rafalski, A. (2003) Contrasting Effects of Selection on Sequence Di- 
versity and Linkage Disequilibrium at Two Phytoene Synthase Loci. The Plant Cell, 15, 1795-1806.

[14] Chandler, K., Lipka, A.E., Owens, B.F., Li, H., Buckler, E.S., Rocheford, T. and Gore, M.A. (2013) Genetic Analysis of Visually Scored Orange Kernel Color in Maize. Crop Science, 53, 189-200. http://dx.doi.org/10.2135/cropsci2012.02.0129

[15] Magalhães, P.C., Durães, F.O.M., Carneiro, N.P. and Paiva, E. (2002) Fisiologia do Milho. Sete Lagoas: EMBRAPACNPMS, 23 (Embrapa-CNPMS. Circular Técnica 22).

[16] American Association of Cereal Chemists (2000) Approved Methods of the AACC, 10th Ed. Approved Methods 44-15A and 6-13. The Association: St. Paul, St. Paul, Minnesota.

[17] Cruz, C.D. (2006) Programa Genes—Estatística Experimental e Matrizes. 1. ed. Viçosa: Editora UFV, 1, 285.

[18] Kandianis, C.B., Stevens, R., Liu, W., Palacios, N., Montgomery, K., Pixley, K., White, W.S. and Rocheford, T. (2013) Genetic Architecture Controlling Variation in Grain Carotenoid Composition and Concentrations in Two Maize Populations. Theoretical and Applied Genetics, 126, 2879-2895.

[19] USDA—Nutrient Database. (2013) http://ndb.nal.usda.gov/ndb/search/list.

[20] Cardoso, W.S., Paes, M.C.D., Galvão, J.C.C., Rios, S.A., Guimarães, P.E.O., Schaffert, R.E. and Borém, A. (2009) Variability of Maize Genotypes for Grain Carotenoid Composition. Variabilidade de Genótipos de Milho Quanto à Composição de Carotenoides nos Grãos. Pesquisa Agropecuária Brasileira, Brasileira, 44, 164-173.

[21] Derera, J., Pillay, K., Siwela, M. and Veldman, F.J. (2011) Consumer Acceptance of Yellow, Provitamin A-Biofortified Maize in KwaZulu-Natal. South African Journal of Clinical Nutrition, 24, 186-191.

[22] Meenakshi, J.V., Banerji, A., Manyong, V., Tomlins, K., Mittal, N. and Hamukwala, P. (2012) Using a Discrete Choice Experiment to Elicit the Demand for a Nutritious Food: Willingness-to-Pay for Orange Maize in Rural Zambia. Journal of Health Economics, 31, 62-71. http://dx.doi.org/10.1016/j.jhealeco.2012.01.002

[23] Stevens, R. and Winter-Nelson, A. (2008) Consumer Acceptance of Provitamin A-biofortified Maize in Maputo, Mozambique. Food Policy, 33, 341-351. http://dx.doi.org/10.1016/j.foodpol.2007.12.003

[24] Harjes, C.E., Rocheford, T.R., Bai, L., Brutnell, T., Kandianis, C.B., Sowinski S.G., et al. (2008) Natural Genetic Variation in Lycopene Epsilon Cyclase Tapped for Maize Biofortification. Science, 319, 330-333. http://dx.doi.org/10.1126/science.1150255

[25] Quackenbush, F.W., Firch, J.G., Rabourn, W.J., McQuistan, M., Petzold, W.N. and Kargl, T.E. (1961) Composition of corn, Analysis of Carotenoids in Corn Grain. Journal of Agricultural and Food Chemistry, 9, 132-135. http://dx.doi.org/10.1021/jf60114a012

[26] Weber, E. (1987) Carotenoids and Tocols of Corn Grain Determined by HPLC. Journal of American Oil Chemistry Society, 64, 1129-1134. http://dx.doi.org/10.1007/BF02612988

[27] Yan, J., Kandianis, C.B., Harjes, C.E., Bai, L., Kim, E.-H., Yang, X., Skinner, D.J., Fu, Z., Mitchell, S., Li, Q., Fernandez, M.G.S., Zaharieva, M., Babu, R., Fu, Y., Palacios, N., Li, J., DellaPenna, D., Brutnell, T., Buckler, E.S., Warburton, M.L. and Rocheford, T. (2010) Rare Genetic Variation at Zea mays crtRB1 Increases b-Carotene in Maize Grain. Nature Genetics, 42, 322-327. http://dx.doi.org/10.1038/ng.551 